\title{
Intervention Program on Adolescent's Creativity Representations and Academic Motivation'
}

\author{
Maria de Fátima Morais ${ }^{2}$ \\ Universidade do Minho, Braga, \\ Portugal
}

\author{
Saul Neves de Jesus \\ Universidade do Algarve, Faro,
}

Portugal

\author{
Ivete Azevedo \\ Universidade do Minho, Braga, \\ Portugal
}

\author{
Alexandra M. Araújo \\ Universidade do Minho, Braga, \\ Portugal
}

\author{
João Viseu \\ Universidade do Algarve, Faro, \\ Portugal
}

\begin{abstract}
Creativity and its promotion are widespread concerns in education. However, few efforts have been made to implement intervention programs designed to promote creativity and other related aspects (e.g., academic motivation). The Future Problem Solving Program International (FPSPI), aimed for training creativity representations and creative problem solving skills in young people, has been one of the most implemented programs. This intervention's materials and activities were adapted for Portuguese students, and a longitudinal study was conducted. The program was implemented during four months, in weekly sessions, by thirteen teachers. Teachers received previous training for the program and during the program's implementation. Intervention participants included 77 Basic and Secondary Education students, and control participants included 78 equivalent students. Pretest-posttest measures of academic motivation and creativity representations were collected. Results suggest a significant increase, in the intervention group, in motivation and the appropriate representations of creativity. Practical implications and future research perspectives are presented.
\end{abstract}

Keywords: adolescents, creativity, educational program evaluation, motivation, representation

\section{Programa de Intervenção nas Representações de Criatividade e Motivação Acadêmica de Adolescentes}

\begin{abstract}
Resumo: A criatividade e sua promoção geram grande preocupação em educação. Contudo, poucos esforços têm existido para implementar programas destinados a sua promoção e de outros aspetos relacionados (e.g., motivação acadêmica). O Future Problem Solving Program International (FPSPI), criado para melhorar as representações de criatividade e a resolução criativa de problemas em jovens, tem sido um dos mais implementados. Os seus materiais e atividades foram adaptados para estudantes portugueses, efetuando-se um estudo longitudinal. O programa foi implementado durante quatro meses, semanalmente, por treze professores, que receberam formação antes e durante a implementação. O grupo experimental incluiu 77 estudantes do Ensino Básico e Secundário, apresentando o grupo de controlo 78 estudantes com características equivalentes. Os dados sobre a motivação e criatividade foram recolhidos num pré e pós-teste. Os resultados sugerem um aumento significativo na motivação e crenças apropriadas de criatividade no grupo experimental. Implicações práticas e perspectivas para investigações futuras são apresentadas.
\end{abstract}

Palavras-chave: adolescentes, criatividade, avaliação de programa educacional, motivação, representação

\section{Programa de Intervención en Representaciones de Creatividad y Motivación Académica de Adolescentes}

\begin{abstract}
Resumen: La creatividad y su promoción generan gran preocupación en educación. Sin embargo, han sido llevados a cabo pocos esfuerzos para implementar programas de promoción de la creatividad y otros aspectos (e.g., motivación académica). El Future Problem Solving Program International (FPSPI), creado para mejorar las representaciones de creatividad y la solución creativa de problemas en jóvenes, ha sido bastante implementado. Se adaptaron sus materiales y actividades para estudiantes portugueses, y se desarrolló un estudio longitudinal. El programa se implementó semanalmente durante cuatro meses por trece profesores, que recibieron formación antes y durante la implementación. El grupo experimental incluyó 77 estudiantes de Educación Primaria y Secundaria y el grupo de control incluyó 78 estudiantes con características semejantes. Los datos de motivación y creatividad fueron recogidos en un pre y post-test, sugiriendo un aumento significativo de motivación y creencias apropiadas sobre la creatividad en el grupo experimental. Se presentan implicaciones prácticas y perspectivas para futuras investigaciones.
\end{abstract}

Palabras clave: adolescentes, creatividad, evaluación de programa educacional, motivación, representación

\footnotetext{
${ }^{1}$ This article is based on the third author's postdoctoral research, under the supervision of the first author and included in the Postdoctoral Program in Psychology of Education of the Institute of Education of the Universidade do Minho.

Support: This study was funded by the Fundação para a Ciência e a Tecnologia (FCT, Portugal - SFRH/BPD/80825/2011).

${ }^{2}$ Correspondence address:

Maria de Fátima Morais. Universidade do Minho, Instituto de Educação. Campus de Gualtar, 4710-057, Braga, Portugal. E-mail: famorais@ ie.uminho.pt
}

Motivation and creativity are becoming increasingly valuable assets in today's unpredictable, ever-changing society (Cropley, 2009; Starko, 2010). Accordingly, educational settings, in particular, should focus on creativity, providing students with creative skills and appropriate representations of creativity (Almeida \& Alencar, 2010). Research has suggested that intrinsically motivated students, who seek to enhance their skills and knowledge, demonstrate 
higher levels of creativity (Jesus, Rus, Lens, \& Imaginário, 2013). Creativity is a multidimensional concept, which has challenged many authors over the years. There are many definitions, explanatory models and even controversy about this concept, showing that, despite its appeal, it is a complex subject (Kaufman, Beghetto, \& Pourjalali, 2011; Starko, 2010). Therefore, it is not surprising that creativity representations involve erroneous viewpoints and that there are many myths or wrong conceptions about creativity, as it is something difficult to know or understand (MacLaren, 2012). However, there are common aspects in the numerous definitions of this construct: creativity is usually referred to the development of something simultaneously new and appropriate, which can be a product or a solution to an existing problem (Lubart, 2007; Runco, 2006).

In turn, the erroneous conceptions about creativity may result in negative personal and social consequences, namely in terms of investing in creative potential, as mental representations condition behavior. Representations, defined as subjective reconstructions of reality, are the condition in which an individual approaches and assesses his or her reality (Moscovici, 2003). One of the most frequently observed myths of creativity is the representation of this construct as something that stems from a sudden and unexplainable inspiration. Many works have dismissed this myth, highlighting the role that effort, persistence and time play in creative ideas (Perkins, 1981; Weisberg, 2006). Based on the representation of creativity as an inspiration, it is still believed that this concept is strongly associated with geniality. However, the importance of creativity in everyday life is broadly acknowledged, suggesting that everyone has a creative potential, which may be intentionally promoted (Fairweather \& Cramond, 2010; Runco, 2006). In addition, creativity is not only originality, but also appropriateness - a frequently forgotten duplicity in the definition of this concept (Kaufman \& Beghetto, 2009; Lubart \& Guinard, 2006). Once more, this definition stresses the role of effort, time and elaboration. Another myth, which is particularly salient in educational settings, links creativity to indiscipline or troubling behavior (Beghetto \& Plucker, 2006; Cropley, 1997). Nevertheless, the expression of creativity does not necessarily result in adjustment problems, as creativity can promote motivation and healthy, adjusted behaviors in daily life (Cropley, 2009). One additional and frequently observed conception of creativity is the one that relates it to arts (Makel \& Plucker, 2010; Péter-Szarka, 2012). This belief may neglect the value of creative ideas for innovation in contexts, such as scientific research, human and social sciences, leadership, or even sports. Creativity is necessary in various domains, from the school years until professional life (Craft, Jeffrey, \& Leibling, 2007; Moraes \& Lima, 2009; Pfeiffer, 2013).

The abovementioned misleading conceptions have been addressed in educational interventions (Aljughaiman \& Mowrer-Reynolds, 2005; Morais \& Azevedo, 2011), as they seem to condition the representations of the creative teacher and of the creative student. For example, the creative teacher may be seen as someone who has difficulties in managing the classroom (Babicka, Dudek, Makiewicz, \& Perzyck, 2010) and the creative student may be expected to present disrupting behaviors (Lucas, 2007). Finally, as creativity representations may constrain teachers' practices for its promotion (Monteiro, Morais, Braga, \& Nakano, 2013; Newton \& Newton, 2009), the prevalence of these representations in students should not be ignored. In Portugal, a survey (Azevedo, 2007) demonstrated that self-reported creativity in adolescents did not correlate with their creative performance or with their teachers' assessments of creativity. From this point of view, positive and appropriate representations of creativity in students may facilitate their self-knowledge and decision-making skills (for vocational or professional decisions, for example), as well as their investment in creative potential. Regarding teachers, previous studies suggested that their own representations of creativity may change due to systematic intervention (Park, Lee, Oliver, \& Cramond, 2006). As these representations may change in teachers, it is possible that students' representations of creativity may also benefit from interventions that aim to deconstruct these myths and promote students' proactivity in creativity development.

Motivation is one of the most important concepts in psychology, as it relates to the explanation of the dynamics, direction and persistence of behavior, considering that all behavior is motivated (Latham \& Pinder, 2005). As in creativity, motivation can also be framed according to several theoretical approaches. Due to the diversity of micro-theories and specific variables studied, there is currently a need for an integrative approach to motivation that merges the contributions of the various theories about this construct. An example of this integrative framework has been presented and empirically tested by Jesus and Lens (2005), combining several theories of motivation. Despite the importance of motivation, it seems that social changes, in the past decades, have resulted in increasing demotivation in various fields of activity. As many suggest (Lévy-Leboyer, 1994), we are experiencing a motivation crisis. The lack of student motivation concerns educators, as students' learning, academic achievement, adjusted behavior, and persistence are highly related to motivation (Rosário, Núñez, Valle, González-Pienda, \& Lourenço, 2013). In 2004, the Organisation for Economic Co-operation and Development [OECD] stressed the importance of motivating students in order to significantly reduce attrition rates. Dropout is a significant problem in Portugal, as the school dropout rate is of $31.2 \%$ (Instituto Nacional de Estatística \& Statistics Portugal, 2013), doubling the average rate of $14.4 \%$ in the European Union (European Commission, 2011). The increasing importance of motivation in academic learning is leading to a greater emphasis on this topic (Jurisevic, 2012; Zenorini \& Santos, 2010), with the objective of exploring possible solutions to engage students in academic tasks and learning (Buijs \& Admiraal, 2013; Diseth, 2011).

Evidence from research suggests that intrinsically motivated students engage in activities to develop skills and knowledge, showing better academic performance and higher levels of self-efficacy (Gottfried, 1990; Pintrich \& Schunk, 2002). A recent meta-analysis has demonstrated significant associations between intrinsic motivation and creativity (Jesus et al., 2013). Characteristics such as curiosity, persistence or openness to experience, for example, are important for 
academic motivation, as well as for creative behavior (Morais, 2013), which illustrates the close relationship between these concepts. Learning tasks that stimulate students' curiosity, persistence, and flexibility, such as those of creative problem solving, allow higher levels of learning motivation associated with these specific tasks, and promote creativity in students' achievement.

Aiming to assist students with the development of their creative potential and other associated dimensions, such as academic motivation, some techniques and training programs have been presented, specifically for the classroom environment (Fairweather \& Cramond, 2010; Starko, 2010), including the Future Problem Solving Program International - FPSPI (E. P. Torrance, J. P. Torrance, Williams, \& Horng, 1978), which will be analyzed in this study. The program's goals follow general guidelines in the literature, suggesting that the promotion of creativity, along with the development of cognitive skills, should also include emotional and social competencies related to creativity (Runco, Lubart, \& Getz, 2012). Creativity is described as a product of a dynamic interaction, or even of a co-incidence of several conditions (Megalakaki, Craft, \& Cremin, 2012; Morais, 2013), as proposed in the explanatory models presented by Amabile (1996), Gardner (2011), or Sternberg and Lubart (1995). Considering an intervention in this dynamic co-incidence of cognition, personality, motivation, and environment, it is expected that creative performance will not improve without the contribution of these various facets, and also that better performances will be observed beyond creative skills.

Creative Problem Solving has its origins in the 50s and is one of the most influential frameworks for training strategies (Sawyer, 2006). This model aims to produce innovative answers, based on divergent and convergent thinking. It includes three main components: (a) understanding the problem; (b) generating solutions; and (c) implementing the solution, in a sequence of six stages, each of which includes the development of divergent production and critical analysis. Creative Problem Solving is based on a combination of cognitive and interpersonal features, and works on knowledge collection, analysis, synthesis, production, assessment, and communication (Isaksen, Dorval, \& Treffinger, 2011). Based on the model of Creative Problem Solving, the Future Problem Solving Program was presented in the 70 s, in the United States of America. The program aims to train creative thinking in children and young people, by exercising their problem solving skills while exploring themes related to the future, based on real life examples (Treffinger, Solomon, \& Woythal, 2012).

The program is now named Future Problem Solving Program International (FPSPI) and is one of the most implemented training programs for creativity (Treffinger, Selby, \& Crumel, 2012) in various countries. An example of the widespread use of this program is an annual international competition where teams of children and adolescents (4th through 12th grade) compete: the International Conference Future Problem Solving (www.fpspi.org). This international conference includes three alternative competition modalities that translate in different ways of presenting a creative project, and which are based on the application of creative problem solving. Specifically, problem solving can be applied to problems in the community (Community Problem Solving) and in domains such as education, culture, or environmental issues. In addition, every year, there is an international proposal of topics such as human rights, healthy living, or genetic tests, which the participants have to analyze and develop creative solutions for an impending problem, considering the future, as the problem is presented through a future scene; this is the modality of Global Issues Problem Solving. There is also a modality of writing futuristic creative texts (Scenario Writing) related to the same mentioned topics. In the first two cases, the program is developed in small groups of children or young people; in the last, the student writes his or her creative text individually. In all modalities, creative projects are mentored by an adult (coach), who can be a teacher, a parent, or another educator. The program can be implemented in the classroom, as well as in extracurricular environments, such as school clubs, community-based groups of young people, or even in the family.

In whichever of these modalities and topics, participants advance through a process of six stages. The first stage corresponds to the identification of generic problems. Subsequently, these fundamental problems are operationalized in specific problems. The third stage is related to the production of solutions, focusing on the quantity and diversity, and not yet having a critical attitude towards these ideas. It is in the next stage that the production and assessment of decision criteria for the aforementioned solutions come to place, in order to, finally, propose an implementation plan for the problem resolution (J. P. Torrance, E. P. Torrance, \& Crabbe, 1983). This process takes place throughout the school year. With the help of a mentor, children or adolescents collect, analyze, and integrate relevant information. They produce and assess ideas, trying to organize an action plan. These students experience a process of Creative Problem Solving involving divergent and logic thinking, which are two fundamental conditions for creativity (Baer, 2003; Kaufman \& Baer, 2006). Throughout this process, the participants also develop competition and cooperation skills (facilitated by teamwork), as well as emotional regulation, establishing interpersonal relationships and dealing with schedules and deadlines. They develop communication skills too, as they are invited to report the project's development (in group or to their mentor) and to present this information in a written assignment or through drawings or videos, for example. Results of the FPSPI have been assessed (Treffinger, Selby et al., 2012), suggesting positive results in cognitive dimensions, namely in creative thinking and in critical and analytical thinking, but also in communication (Cojorn, Koocharoenpisal, Haemaprasith, \& Siripankaew, 2012), career and occupational planning (Cramond, 2002), and in motivation for teamwork (Alvino, 1993). Moreover, creative problem solving skills seem to be developed not only in children and adolescents participating in the program, but also in the program's coaches (Margison, 2004).

The current study aimed to examine a program that promotes creative problem solving in adolescents, analyzing its impact on students' representations of creativity and academic 
motivation. We hypothesized that the FPSPI contributes to the improvement of both aspects in an experimental group.

\section{Method}

\section{Participants}

The intervention program was administered to 77 students who attended the 7 th to 12 th grades in Portuguese schools. These students were 12 to 17 years old $(M=14.47, S D=2.25)$, being $54.2 \%$ boys $(n=42)$ and $45.8 \%$ girls $(n=35)$. The control group included 78 students with equivalent characteristics, of the same school years, and being roughly half boys $(n=36 ; 45.8 \%)$ and girls ( $n=42 ; 54.2 \%)$, as observed in the experimental group. The participants in the control group attended the same educational establishments and educational levels of the participants in the experimental group, and were included in similar age groups.

\section{Instruments}

Both in the pretest and posttest, students completed the School and Creativity Scale - Students' Perceptions (Azevedo \& Morais, 2012; Azevedo, Morais, Jesus, Ribeiro, \& Brandão, 2012). This scale assesses representations of creativity and creative teachers/students, and includes 25 five-point Likerttype items $(1=$ completely disagree to $5=$ completely agree $)$. Items are constructed based on explicit theories of creativity (e.g., "Creativity is finding a relation between different ideas"), as well as on myths or distortions frequently associated to this concept (e.g., "Creativity has to do with being an artist"). The development of this measure included an initial content analysis of items, performed by an expert in creativity, and an exploratory study with 10 adolescents, who completed the scale in order to clarify the formulation of the items for the age range considered. The scale is composed by two factors, corresponding to Appropriate Representations (15 items) and to Erroneous Representations (Myths; 10 items). In the present study, the first factor presented a Cronbach's alpha of .84 and the second. 76.

Participants also completed the Portuguese version of the Scale of Motivation for Academic Learning (Imaginário et al., 2014), which is based on the work of Siqueira and Wechsler (2006). This scale presents a unidimensional structure, assessing motivation for learning, a specific aspect of motivation. This instrument is composed of 14 items in a six-point Likert-type scale (e.g., "When I have problems in a task, I ask my teacher for help"), and presented a Cronbach's alpha of .82 in the current study.

\section{Procedure}

Data collection. The program's assessment included a control group and an experimental group, as well as two repeated measures (pretest and posttest). Assessment happened at the same time for both groups and data collection was conducted in the classroom after obtaining the permission of the schools' principals and students' parents, who were informed about the purpose of the study. The sequence of tasks was the same for all students in both groups and at both assessment times. The control group did not attend the sessions of the FPSPI program. The program (FPSPI) was implemented during four months, in weekly sessions of 45 minutes, by thirteen teachers. Teachers received previous training for the program and, during the program's implementation, they participated in biweekly meetings with the third author of this paper, who is the coordinator of the program in Portugal.

Data analysis. Data analysis was performed using the Statistical Package for Social Sciences (SPSS). A MannWhitney t-test was conducted to compare the results of the experimental and control groups. This test was performed since, in both groups, the samples' normality criteria was not respected, as evaluated following the assumptions of Field (2009).

\section{Ethical Considerations}

This research project received approval from the Consulting Board of the Research Centre for Spatial and Organizational Dynamics (CIEO - Universidade de Algarve, Portugal). Students were requested to sign an Informed Consent and anonymity and confidentiality were assured.

\section{Results}

The assessment of the program's impact was conducted by comparing the results between the experimental and control groups. Table 1 presents the results in the pretest phase. Results show that, before the implementation of the program, there were no significant differences between the experimental and control group in the variables creativity representations (appropriate and erroneous conceptions) and academic motivation.

Table 1

Pretest Results of the Experimental and Control Groups

\begin{tabular}{|c|c|c|c|c|}
\hline & Groups & $\mathrm{MR}^{\mathrm{c}}$ & $U^{\mathrm{d}}$ & $p$ \\
\hline \multirow{2}{*}{ Appropriate Representations } & $\mathrm{CG}^{\mathrm{a}}$ & 56.53 & \multirow{2}{*}{1085.00} & \multirow{2}{*}{$n s^{\mathrm{e}}$} \\
\hline & $\mathrm{EG}^{\mathrm{b}}$ & 47.20 & & \\
\hline \multirow{2}{*}{ Erroneous Representations } & CG & 57.31 & \multirow{2}{*}{1043.50} & \multirow{2}{*}{$n s$} \\
\hline & EG & 46.37 & & \\
\hline \multirow{2}{*}{ Academic Motivation } & CG & 56.32 & \multirow{2}{*}{1550.50} & \multirow{2}{*}{$n s$} \\
\hline & EG & 62.86 & & \\
\hline
\end{tabular}


Differences between pretest and posttest scores were calculated to assess the program's impact on appropriate and erroneous representations of creativity and student motivation. Results suggest that there are statistically significant differences between the experimental and control group, both for academic motivation and appropriate representations of creativity, which are favorable to the experimental group. Differences were also observed for erroneous representations (myths) which, although favorable for the experimental group, are not statistically significant (Table 2).

Table 2

Differences in Pretest and Posttest Scores in the Experimental and Control Groups

\begin{tabular}{|c|c|c|c|c|}
\hline & Groups & $\mathrm{MR}^{\mathrm{c}}$ & $U^{\mathrm{d}}$ & $p$ \\
\hline \multirow{2}{*}{ Appropriate Representations } & $\mathrm{CG}^{\mathrm{a}}$ & 41.51 & \multirow{2}{*}{769.00} & \multirow{2}{*}{$<.001$} \\
\hline & $\mathrm{EG}^{\mathrm{b}}$ & 63.12 & & \\
\hline \multirow{2}{*}{ Erroneous Representations } & $\mathrm{CG}$ & 53.42 & \multirow{2}{*}{1250.00} & \multirow{2}{*}{$n s^{\mathrm{e}}$} \\
\hline & EG & 50.50 & & \\
\hline \multirow{2}{*}{$\begin{array}{l}\text { Academic } \\
\text { Motivation }\end{array}$} & CG & 52.59 & \multirow{2}{*}{1356.00} & \multirow{2}{*}{$.039 *$} \\
\hline & EG & 65.75 & & \\
\hline
\end{tabular}

\section{Discussion}

Nowadays, the promotion of creativity in educational settings is a widespread concern (Fairweather \& Cramond, 2010; Starko, 2010). In this study, we presented the Future Problem Solving Program International (FPSPI), a program to train creative problem solving skills in young people.

Changes were observed in the pretest and posttest moments since, in the second moment, statistically significant differences were found for appropriate representations of creativity and academic motivation. Given the absence of baseline statistically significant differences between both groups in the three evaluated variables, the changes observed in the posttest may be interpreted as a result of the FPSPI intervention, and thus suggest the program's effectiveness. On the one hand, the increase in motivation for school learning, which was observed in the experimental group, reveals the effectiveness of this intervention in creative problem solving skills not only at a cognitive, but also at an emotional level (Runco et al., 2012), confirming other results obtained with this program, namely concerning motivation (Alvino, 1993). The current findings may be influenced by the relationship between creativity and motivation (Eisenberger \& Rhoades, 2001; Jesus et al., 2013), as there are communalities in the concepts' definitions, including curiosity or persistence (Cropley, 2009; Morais, 2013). In fact, according to several theoretical models, creativity cannot be expressed without showing high levels of intrinsic motivation (Amabile, 1985; Sternberg \& Lubart, 1995). Moreover, the intervention program included, in the initial sessions, the clarification of the creativity concept, and of what being creative means, as well as the training of specific creative skills (such as flexibility, remote association of ideas, and the production of alternatives). Conditions were created for students to have clear and accurate representations of creativity. However, if research has shown that these representations can change, it has also indicated that this challenge does not happen without problems (Park et al., 2006). In this case, results may suggest that it is easier for these students to assimilate appropriate beliefs about what is creativity (significant differences are observed only in this dimension of representations), than to change the erroneous representations corresponding to myths, which have been observed for decades.

Although the program was initially developed for creativity promotion, the close relationship existing between motivation and creativity contributes to the understanding of this study's results. The obtained results also suggest the importance of planning instruction and learning, in order to meet students' curiosity and provide them the opportunity to express their creativity in learning. Therefore, in addition to the influence that this intervention may have in creativity (Cramond, 2009), the observed impact on students' academic motivation represents an important contribution to solve one of the most salient problems in education, in most European countries, which is the lack of motivation for studying (Katz, Eilot, \& Nevo, 2014; Vansteenkiste, Sierens, Soenens, Luyckx, \& Lens, 2009).

In sum, the present paper demonstrated that the Future Problem Solving Program International (FPSPI) contributed to the improvement of the participants' appropriate representations of creativity, allowing, simultaneously, an enhancement of their academic motivation. However, the program was not effective at changing the students' erroneous representations of creativity. These findings suggest that the FPSPI can be a useful tool in educational settings.

This study presents some limitations worth considering. The sample size was the major limitation of this research. A reduced sample, with few participants in each group, may not provide as accurate results as a sample with more participants per group. In addition, the use of Likerttype scales may be regarded as a limitation. These scales 
might present a number of answer options the respondents consider insufficient to express their opinion, or participants may not understand the category labels available for their answers (Maeda, 2015; Weijters, Geuens, \& Baumgartner, 2013). Furthermore, these scales only provide quantitative information, which prevents researchers from accessing the actual opinion of the participants about the variables studied (Weijters et al., 2013). Moreover, the fact that the instruments were the same at both moments (i.e., pretest and posttest), while allowing the respondents to get some level of familiarity with the items, might have contributed to a better performance in the posttest moment, and possibly explained the differences observed between the two test moments (Anastasi \& Urbina, 2000). Finally, the absence of another posttest, conducted in an extended period of time after the intervention (i.e., a follow-up assessment), might have been useful to observe if the results of the intervention program remained the same over the time.

In the future, studies may use larger sample sizes in order to allow more reliable comparisons between the experimental and the control groups. In addition, the use of other instruments in the posttest moment might prevent possible training effects. The realization of a follow-up posttest may be important to observe if the effects of the intervention are consistent over time. Research should also focus on the impact of this program on learning difficulties, aiming to improve students' motivation and appropriate representations of creativity, as well as assessing the program's impact on school achievement. Furthermore, the implementation of this program in other student populations, namely in university students, could serve to test its effectiveness in other school contexts. Although this study has not focused on gifted students, the benefits of this program as a training tool for this group of students is evident, due to its goals and based on this study's results. According to various theoretical paradigms, giftedness involves creativity and high levels of motivation (Miller, 2012; Terry, Bohnenberger, Renzulli, Cramond, \& Sisk, 2008). In this order of ideas, future interventions may be conducted with gifted students, aiming to compare the effects of this program with the effects observed in other students, namely with students who present learning difficulties (Alves \& Nakano, 2014). The program can be more effective in some specific student populations and, if this is observed, modifications in the FPSPI should be suggested, in order to adapt the program to students' characteristics and allowing it to be implemented in a wider range of populations.

\section{References}

Aljughaiman, A., \& Mowrer-Reynolds, E. (2005). Teachers' conceptions of creativity and creative students. Journal of Creative Behavior, 39(1), 17-34. doi:10.1002/j.2162-6057. tb01247.x

Almeida, J. M. O., \& Alencar, E. M. L. S. (2010). Criatividade no ensino médio segundo os seus estudantes [Creativity in high school according to students]. Paidéia (Ribeirão Preto), 20(47), 325-334. doi:10.1590/S0103863X2010000300005
Alves, R. J. R., \& Nakano, T. C. (2014). Creativity and intelligence in children with and without developmental dyslexia. Paidéia (Ribeirão Preto), 24(59), 361-369. doi:10.1590/1982-432772459201410

Alvino, J. (1993). Teaching our children to solve "fuzzy" problems. PTA Today, 18(5), 13-14.

Amabile, T. M. (1985). Motivation and creativity: Effects of motivational orientation on creative writers. Journal of Personality and Social Psychology, 48(2), 393-399. doi:10.1037//0022-3514.48.2.393

Amabile, T. M. (1996). Creativity in context: Update the social psychology of creativity. Boulder, CO: Westview.

Anastasi, A., \& Urbina, S. (2000). Testagem psicológica [Psychological testing] (M. A. V. Verenese, Trans., 7th ed.). Porto Alegre, RS: Artmed.

Azevedo, I. (2007). Criatividade e percurso escolar: Um estudo com jovens do ensino básico [Creativity and school courses: A study with middle school students] (Doctoral dissertation). Retrieved from http://hdl.handle. net $/ 1822 / 8065$

Azevedo, I., \& Morais, M. F. (2012). Avaliação da criatividade como condição para o seu desenvolvimento: Um estudo português do teste de pensamento criativo de Torrance em contexto escolar [Creativity assessment as a condition for its development: A Portuguese study of the Torrance creative thinking test in school context]. REICE: Revista Iberoamericana sobre Calidad, Eficacia y Cambio en Educación, 10(2), 41-55.

Azevedo, I., Morais, M. F., Jesus, S., Ribeiro, I., \& Brandão, S. (2012). A aplicação do Future Problem Solving Program International em adolescentes: Um estudo exploratório [The application of the Future Problem Solving Program International in Portuguese adolescents: An exploratory study]. AMAzônica: Revista de Psicopedagogia, Psicologia Escolar e Educação, 10(3), 24-47.

Babicka, A., Dudek, P., Makiewicz, M., \& Perzycka, E. (2010). Competencia creativa del profesor [Teacher's creative competence]. Revista Electrónica Interuniversitaria de Formación del Profesorado, 13(1), 51-61. Retrieved from http://www.redalyc.org/articulo.oa?id=217014922006

Baer, J. (2003). Evaluative thinking, creativity and task specificity: Separating wheat from chaff is not the same as finding needles in haystacks. In M. A. Runco (Ed.), Critical creative processes: Perspectives on creativity research (pp. 129-151). Cresskil, NJ: Hampton Press.

Beghetto, R. A., \& Plucker, J. A. (2006). The relationship among schooling, learning and creativity: "All roads lead to creativity" or "you can't get there from here"? In J. C. Kaufman \& J. Baer (Eds.), Creativity and reason in cognitive development (pp. 316-332). New York, NY: Cambridge University Press.

Buijs, M., \& Admiraal, W. (2013). Homework assignments to enhance student engagement in secondary education. European Journal of Psychology of Education, 28(3), 767-779. doi:10.1007/s10212-012-0139-0

Cojorn, K., Koocharoenpisal, N., Haemaprasith, S., \& Siripankaew, P. (2012). Effects of the Creative Problem 
Solving (CPS) learning model on matter and properties of matter for seventh grade students. Journal of Education, 35(1), 18-30.

Craft, A., Jeffrey, B., \& Leibling, M. (2007). Creativity in education. London, United Kingdom: Continuum.

Cramond, B. (2002). The study of creativity in the future. In A. G. Aleinikov (Ed.), The future of creativity (pp. 83-89). Bensenville, IL: Scholastic Testing Service.

Cramond, B. (2009). Future problem solving in gifted education. In L. Shavinina (Ed.), International handbook on giftedness (pp. 1143-1156). New York, NY: Springer.

Cropley, A. J. (1997). Fostering creativity in the classroom: General principles. In M. A. Runco (Ed.), The creativity research handbook (Vol. 1, pp. 83-114). Cresskill, NJ: Hampton Press.

Cropley, A. J. (2009). Creativity in education and learning: A guide for teachers and educators. New York, NY: RoutledgeFalmer.

Diseth, A. (2011). Self-efficacy, goal orientations and learning strategies as mediators between preceding and subsequent academic achievement. Learning and Individual Differences, 21(2), 191-195. doi:10.1016/j. lindf.2011.01.003

Eisenberger, R., \& Rhoades, L. (2001). Incremental effects of reward on creativity. Journal of Personality and Social Psychology, 81(4), 728-741. doi:10.1037//00223514.81.4.728

European Commission. (2011). Grade retention during compulsory education in Europe: Regulations and statistics. Brussels, Belgium: Education, Audiovisual and Culture Executive Agency.

Fairweather, E., \& Cramond, B. (2010). Infusing creative and critical thinking into the curriculum together. In R. A. Beghetto \& J. C. Kaufman (Eds.), Nurturing creativity in the classroom (pp. 113-141). New York, NY: Cambridge University Press.

Field, A. (2009). Discovering statistics using SPSS (3rd ed.). Thousand Oaks, CA: Sage.

Gardner, H. E. (2011). Creating minds: An anatomy of creativity seen through the lives of Freud, Einstein, Picasso, Stravinsky, Eliot, Graham, and Gandhi. New York, NY: Basic Books.

Gottfried, A. E. (1990). Academic intrinsic motivation in young elementary school children. Journal of Educational Psychology, 82(3), 525-538. doi:10.1037//00220663.82.3.525

Imaginário, S., Jesus, S. N., Morais, F., Fernandes, C., Santos, R., Santos, J., \& Azevedo, I. (2014). Motivação para a aprendizagem escolar: Adaptação de um instrumento de avaliação para o contexto português [Motivation for school learning: Adaptation of an evaluation instrument for the Portuguese context]. Revista Lusófona de Educação, 28(28), 91-105.

Instituto Nacional de Estatística, \& Statistics Portugal. (2013). Retrato territorial de Portugal2011 [Territorial portrait of Portugal 2011]. Lisboa, Portugal: INE, I.P.
Isaksen, S. G., Dorval, K. B., \& Treffinger, D. J. (2011). Creative approaches to problem solving: A framework for innovation and change (3rd ed.). Thousand Oaks, CA: Sage.

Jesus, S. N., \& Lens, W. (2005). An integrated model for the study of teacher motivation. Applied Psychology: An International Review, 54(1), 119-134. doi:10.1111/ j.1464-0597.2005.00199.x

Jesus, S. N., Rus, C. L., Lens, W., \& Imaginário, S. (2013). Intrinsic motivation and creativity related to product: A meta-analysis of the studies published between 19902010. Creativity Research Journal, 25(1), 80-84. doi:10 $.1080 / 10400419.2013 .752235$

Jurisevic, M. (2012). Students' motivational patterns to learn. Studia Psychologica, 54(3), 221-236.

Katz, I., Eilot, K., \& Nevo, N. (2014). “I'll do it later": Type of motivation, self-efficacy and homework procrastination. Motivation and Emotion, 38(1), 111-119. doi:10.1007/ s11031-013-09366-1

Kaufman, J. C., \& Baer, J. (2006). Hawking's Haiku, Madonna's math: Why it is hard to be creative on every room of the house? In R. J. Sternberg, E. L. Grigorenko, \& J. L. Singer (Eds.), Creativity: From potential to realization (pp. 3-20). Washington, DC: APA.

Kaufman, J. C., \& Beghetto, R. A. (2009). Beyond big and little: The four $\mathrm{C}$ model of creativity. Review of General Psychology, 13(1), 1-12. doi:10.1037/a0013688

Kaufman, J. C., Beghetto, R. A., \& Pourjalali, S. (2011). Criatividade na sala de aula: Uma perspectiva internacional [Creativity in the classroom: An international perspective]. In S. M. Wechsler \& V. L. T. Souza (Orgs.), Criatividade e aprendizagem: Caminhos e descobertas em perspectiva internacional [Creativity and learning: Pathways and discoveries from an international perspective] (pp. 53-72). São Paulo, SP: Loyola.

Latham, G. P., \& Pinder, C. C. (2005). Work motivation theory and research at the Dawn of the twenty-first century. Annual Review of Psychology, 56, 485-516. doi:10.1146/ annurev.psych.55.090902.142105

Lévy-Leboyer, C. (1994). A crise das motivações [The crisis of the motivations] (C. W. Bergamin \& R. Coda, Trans.). São Paulo, SP: Atlas.

Lubart, T. (2007). Psicologia da criatividade [Psychology creativity] (M. C. M. Moraes, Trans.). Porto Alegre, SP: Artmed.

Lubart, T., \& Guinard, J. H. (2006). The generality-specificity of creativity: A multivariate approach. In R. J. Sternberg, E. L. Grigorenko, \& J. L. Singer (Eds.), Creativity: From potential to realization (pp. 43-56). Washington, DC: APA.

Lucas, B. (2007). Creative thinking, teaching creativity and creative learning. In A. Craft, B. Jeffrey, \& M. Leibling (Eds.), Creativity in education (pp. 35-44). London, United Kingdom: Continuum.

MacLaren, I. (2012). The contradictions of policy and practice: Creativity in higher education. 
London Review of Education, 10(2), 159-172. doi:10.1080/1478460.2012.691281

Maeda, H. (2015). Response option configuration of online administered Likert scales. International Journal of Social Research Methodology, 18(1), 15-26. doi:10.108 0/13645579.2014.885159

Makel, M. C., \& Plucker, J. A. (2010). Creativity. In S. I. Pfeiffer (Ed.), Handbook of giftedness in children: Psycho-educational theory, research, and best practices (pp. 247-270). New York, NY: Springer.

Margison, J. (2004). Future Problem Solving Program coaches' efficacy in teaching for successful intelligence and their patterns of successful behavior. Roeper Review, 26(3), 175.

Megalakaki, O., Craft, A., \& Cremin, T. (2012). The nature of creativity: Cognitive and confluence perspectives. Electronic Journal of Research in Educational Psychology, 10(3), 1035-1055.

Miller, A. L. (2012). Conceptualizations of creativity: Comparing theories and models of giftedness. Roeper Review, 34(2), 94-103. doi:10.1080/83193.2012.660683

Monteiro, A. S., Morais, M. F., Braga, A. C., \& Nakano, T. (2013). Representações sobre criatividade: Diferenças entre docentes portugueses do ensino básico e secundário [Representations of creativity: Differences between Portuguese teachers of elementary and secondary education]. AMAzônica: Revista de Psicopedagogia, Psicologia Escolar e Educação, 6(1), 327-357.

Moraes, M. M., \& Lima, S. M. V. (2009). Estratégias para criar no trabalho: Proposição teórica e validação psicométrica de medida [Creative strategies at work: Theoretical proposition and validation of psychometric measure]. Paidéia (Ribeirão Preto), 19(44), 367-377. doi:10.1590/S0103-863X200900030011

Morais, M. F. (2013). Creativity: Challenges to a key concept for the twenty-first century. In A. Antonietti, B. Colombo, \& D. Memmert (Eds.), Psychology of creativity: Advances in theory, research and application (pp. 3-19). Hauppauge, NY: Nova Science.

Morais, M. F., \& Azevedo, I. (2011). Escutando os professores portugueses acerca da criatividade: Alguns resultados e reflexões sobre a sua formação [Listening Portuguese teachers about creativity: Some results and reflections on their training]. In S. M. Wechsler \& $\mathrm{T}$. C. Nakano (Orgs.), Criatividade no ensino superior: Uma perspectiva internacional [Creativity in higher education: An international perspective] (pp. 140-179). São Paulo, SP: Vetor.

Moscovici, S. (2003). Representações sociais: Investigações em psicologia social [Social representations: Explorations in social psychology] (P. A. Guareschi, Trans.). Petrópolis, RJ: Vozes.

Newton, D. P., \& Newton, L. D. (2009). Some student teacher's conceptions of creativity in school science. Research in Science \& Technological Education, 27(1), 45-60. doi:10.1080/02635140802658842

Organisation for Economic Co-operation and Development.
(2004). Education at a glance. OECD Indicators. Paris, France: OECD.

Park, S., Lee, S.-Y., Oliver, J. S., \& Cramond, B. (2006). Changes in Korean science teacher's perceptions of creativity and science teaching after participating in an overseas professional development program. Journal of Science Teacher Education, 17(1), 37-64. doi:10.1007/ s10972-006-9009-4

Perkins, D. N. (1981). The mind's best work. Cambridge, MA: Harvard University Press.

Péter-Szarka, S. (2012). Creative climate as a means to promote creativity in the classroom. Electronic Journal of Research in Educational Psychology, 10(3), 1011-1034.

Pfeiffer, S. I. (2013). Serving the gifted: Evidence-based clinical and psychoeducational practice. New York, NY: Routledge.

Pintrich, P. R., \& Schunk, D. H. (2002). Motivation in education: Theory, research and applications. Upper Saddle River, NJ: Merril Prentice Hall.

Rosário, P., Núñez, J., Valle, A., González-Pienda, J., \& Lourenço, A. (2013). Grade level, study time, and grade retention and their effects on motivation, self-regulated learning strategies, and mathematics achievement: A structural equation model. European Journal of Psychology of Education, 28(4), 1311-1331. doi:10.1007/ s10212-012-0167-9

Runco, M. A. (2006). Everyone has creative potential. In R. J. Sternberg, E. L. Grigorenko, \& J. L. Singer (Eds.), Creativity: From potential to realization (pp. 21-30). Washington, DC: APA.

Runco, M. A., Lubart, T. I., \& Getz, I. (2012). Creativity and economics. In M. A. Runco (Ed.), The creativity research handbook (Vol. 2, pp. 173-198). Cresskill, NJ: Hampton Press.

Sawyer, R. K. (2006). Explaining creativity: The science of human innovation. New York, NY: Oxford University Press.

Siqueira, L. G. G., \& Wechsler, S. M. (2006). Motivação para a aprendizagem escolar: Possibilidade de medida [Motivation for school learning: Measurement possibilities]. Avaliação Psicológica, 5(1), 21-31.

Starko, A. J. (2010). Creativity in the classroom: Schools of curious delight. New York, NY: Routledge.

Sternberg, R. J., \& Lubart, T. I. (1995). Defying the crowd: Cultivating creativity in a culture of conformity. New York, NY: The Free Press.

Terry, A. W., Bohnenberger, J. E., Renzulli, J. S., Cramond, B., \& Sisk, D. (2008). Vision with action: Developing sensitivity to societal concerns in gifted youth. Roeper Review, 30(1), 61-67. doi:10.1080/0278319071836478

Torrance, E. P., Torrance, J. P., Williams, S. J., \& Horng, R. Y. (1978). Handbook for training future problem solving teams. Athens, GA: University of Georgia.

Torrance, J. P., Torrance, E. P., \& Crabbe, A. B. (1983). Handbook for training FPS teams: 1983-84 Edition. Cedar Rapids, IA: Future Problem Solving Program/Coe College. 
Treffinger, D. J., Selby, E. C., \& Crumel, J. H. (2012). Evaluation of the Future Problem Solving Program International (FPSPI). International Journal of Creativity and Problem Solving, 22(2), 45-61.

Treffinger, D. J., Solomon, M., \& Woythal, D. (2012). Four decades of creative vision: Insights from an evaluation of the Future Problem Solving Program International (FPSPI). The Journal of Creative Behavior, 46(3), 209219. doi:10.1002/jocb.14

Vansteenkiste, M., Sierens, E., Soenens, B., Luyckx, K., \& Lens, W. (2009). Motivational profiles from a selfdetermination perspective: The quality of motivation matters. Journal of Educational Psychology, 101(3), 671688. doi:10.1037/a0015083

Weijters, B., Geuens, M., \& Baumgartner, H. (2013). The effect of familiarity with the response category labels on item response to Likert scales. Journal of Consumer Research, 40(2), 368-381. doi:10.1086/670394

Weisberg, R. W. (2006). Expertise and reason in creative thinking: Evidence from case studies and the laboratory. In J. C. Kaufman \& J. Baer (Eds.), Creativity and reason in cognitive development (pp. 7-42). New York, NY: Cambridge University Press.

Zenorini, R. P. C., \& Santos, A. A. A. (2010). Escala de metas de realização como medida de motivação para a aprendizagem [Achievement goals scale as a measure of motivation for learning]. Interamerican Journal of Psychology, 44(2), 291-298.

Maria de Fátima Morais is an Assistant Professor at the Institute of Education, Universidade do Minho.

Saul Neves de Jesus is a Full Professor at Universidade do Algarve.

Ivete Azevedo is the Director of the Torrance Center Portugal and a postdoctoral researcher at the Institute of Education of the Universidade do Minho.

Alexandra M. Araújo is a postdoctoral researcher at the Institute of Education of the Universidade do Minho.

João Viseu is a Ph.D. researcher at the Research Centre for Spatial and Organizational Dynamics (CIEO) of the Universidade do Algarve.

Received: Nov. 7, 2014

1st Revision: Apr. 27, 2015

Approved: May 5, 2015

How to cite this article:

Morais, M. de F., Jesus, S. N., Azevedo, I., Araújo, A. M., \& Viseu, J. (2015). Intervention program on adolescent's creativity representations and academic motivation. Paidéia (Ribeirão Preto), 25(62), 289-297. doi:10.1590/1982-43272562201502 